\title{
The influence of school facilities and the work environment on teachers performance
}

\author{
Eka Purnama Sari ${ }^{1}$, Syarwani Ahmad ${ }^{2}$, Destiniar ${ }^{2}$ \\ ${ }^{1}$ Sekolah Dasar Negeri Gugus 3 Lengkiti, Indonesia \\ ${ }^{2}$ Universitas PGRI Palembang, Indonesia
}

\begin{tabular}{l} 
Article Info \\
\hline Article history: \\
Received Jul $8^{\text {th }}, 2021$ \\
Revised Aug $19^{\text {th }}, 2021$ \\
Accepted Aug $30^{\text {th }}, 2021$ \\
\hline
\end{tabular}

\section{Keyword:}

Influence of infrastructure

Teacher performance

\begin{abstract}
This study aims to determine the effect of infrastructure and work environment together on the performance of public elementary school teachers in Gugus 3, Lengkiti District. In this study, using quantitative research methods and research design in the form of influence studies, namely to determine the effect of the three variables, namely the independent variable or free school infrastructure (X1), work environment (X2) and the dependent or dependent variable Teacher Performance $(\mathrm{Y})$. The results of the study can be concluded as follows: 1) There is a significant influence between school infrastructure on the performance of teachers at SD Negeri Gugus 3, Lengkiti District, 2) There is a significant influence between the work environment on the performance of teachers at SD Negeri Gugus 3, Lengkiti District, 3) There is an influence between the school infrastructure and the environment together on the performance of teachers at SD Negeri Gugus 3, Lengkiti District.
\end{abstract}

(C) 2021 The Authors. Published by IICET.

This is an open access article under the CC BY-NC-SA license

(https://creativecommons.org/licenses/by-nc-sa/4.0

\section{Corresponding Author:}

Sari, E. P.,

Sekolah Dasar Negeri Gugus 3 Lengkiti, Indonesia

Email: ekapurnama1503sari@gmail.com

\section{Introduction}

In this era of globalization, it is very important to improve the quality of human resources which is absolutely necessary. Especially in the face of changes and developments that are increasing rapidly. Therefore, the education system plays an important role in the development of quality human and human resources. When viewed in terms of quantity, the progress of education in Indonesia is quite encouraging, however, in terms of quality, the development is still not evenly distributed in various aspects (Sukmadinata et al., 2006). The opinion according to Sudjana (2000) states that there is an effort made to anticipate these problems, namely by implementing development in the field of education, because by improving the quality of education, the quality of human resources will also increase.

Judging from the explanation above, it can be explained that the importance of quality Human Resources education, so that it can require the government to focus more on developing knowledgeable, creative and independent Human Resources.

The same is the case with the explanation stated in Law no. 20 of 2003 Chapter II Article 3 which states that National Education functions in developing abilities and shaping the character and civilization of the nation, and aims to develop the potential and abilities of students to become human beings who believe and have devotion to God Almighty, have a noble character, are healthy, knowledgeable, competent, creative, independent and be a democratic and responsible citizen. Basically education is a conscious effort that is 
deliberately designed to achieve predetermined goals and contains personality development. According to Syafaruddin (2008: 2) states that education has the aim of helping the younger generation develop all elements of their personal potential both spirituality, morality, sense of sociality, and rationality. In addition, education also aims to improve the quality of human resources, one of which can be seen from the quality of the educational institution.

In line with this, Yusutria (2017) said that the low quality of education causes the quality of human resources to be low, the higher the level of education, the higher the quality of human resources. Schools as educational institutions in which there are school principals, teachers, management staff, students and parents of students who have a role in the formation of Human Resources. Various methods and methods of learning carried out by the teacher to improve student abilities are shown aimed at the quality of the school where they work.

According to Chamundeswari (2013) "The teacher's job is therefore to show what to study, to challenge the students by setting high standards and to criticize in order to spur to further achievement, to help surmount blind spots and evaluate each student's progress in term of valid. objectives".

The learning strategy made by the teacher will be able to show optimal abilities in school success. The form of success in question is that it can be shown in the performance of a teacher.

According to Supardi (2013: 14), which states that teacher performance is a condition that indicates a person's ability to carry out his duties at school and describes the activities carried out by the teacher in implementing learning. Meanwhile, Usman (2008: 464) says that teacher performance in learning has a major factor in achieving educational goals, this is because teachers are the spearhead in the world of education, the high and low quality of teacher performance results in student achievement in school. The increase in teacher performance in learning is influenced by several factors, including: salary, infrastructure, physical work environment conditions, leadership.

This is in line with the research of Bongani Kumalo (2014) which concluded that "What this study seems to show is that participants identified resources and the availability of supporting infrastructue as crucial in ensuring that the learning and teaching context functions maximally"

Apart from some of the factors above, there is also another relationship in this study, namely the infrastructure which is a factor in improving teacher performance. Provision of good and complete infrastructure will support school activities in order to achieve optimal results. However, it is the case that there are still schools whose infrastructure is incomplete and some whose infrastructure is complete.

However, it is the utilization that is still not done by the teacher so that the teacher's performance is not optimal because there are still teachers using conventional media in the learning process. This was also strengthened by the results of previous interviews with teachers in several SD Negeri Gugus 3, Lengkiti District, one of which was SD Negeri 79 OKU through a representative for facilities and infrastructure.

From the interview, information was obtained that the school had inadequate or incomplete infrastructure so that its utilization was not optimal, the teacher made more use of textbooks as the main source of the learning process. From the results of the information obtained that the infrastructure advice in schools has begun to be complete, only the use of facilities and infrastructure, especially for learning activities has not been fully carried out, this is because the use of facilities, especially teaching aids, practical tools and media takes a lot of time, while the conditions of learning time are limited availability, so that teachers use more textbook facilities for teaching and learning activities. Apart from facilities and infrastructure, there are other factors that also affect teacher performance, namely work environment factors. According to the productivity report of the International Labor Office (ILO) in Barnawi and Arifin (2014: 54), there is the first thing that must be done to improve teacher performance, this is to ensure that teachers can carry out their duties in a condition that meets the requirements. Thus, teachers can carry out their duties without experiencing tensions or in other words the government must provide a good work environment for teachers.

With a good work environment, it can create a conducive work relationship between the people in the work environment. According to Mulyasa (2013: 193), he explains that to create a conducive work environment, at least two things are needed, including the teacher himself and a good relationship between teachers and parents and the community in the surrounding environment.

Agreeing with the above, Usman (2008: 467) also said that supportive working conditions are needed which is a comfortable work environment to work. A good work environment will facilitate them to work better too. 
Workers will prefer physical conditions that are not dangerous or comfortable in their work environment. Besides that, most of them prefer a workplace that is relatively close to the location where the workers live. However, in the implementation it is often not as expected by the school, a bad work environment will affect individual teachers, so that the responsibility as an education provider is not optimal, starting from the work environment which concerns the physical condition of the school, for example the comfort of the work space and school infrastructure as well as a work environment that involves a psychological condition such as unpleasant feelings between teachers and leaders, this of course is thought to affect the performance of a teacher.

In line with research conducted by Mila Yumaroh and Lili Andriani (2017), the results of this study indicate that the increase or decrease in teacher performance is strongly influenced by several factors, both internal and external factors, one of the external factors that influence teacher performance, namely the environment. work. As for what distinguishes this researcher is the object of research, in this study the object is the teacher at SMK, while in this study the object is the teacher of SD Negeri Gugus 3, Lengkiti District. The difference is in the $\mathrm{x} 2$ variable used by the researcher, as well as the different populations or samples used. The equation is in the variables $y$, xa and the agency level that the researcher uses.

Research conducted by Anggraini et al (2020) which shows the results of the study that 1) infrastructure affects teacher performance; 2) the work environment affects teacher performance; 3 ) infrastructure and work environment jointly influence teacher performance. Where this research has the same title, but there are differences that are located in the population, research sample and research institutions carried out.

\section{Method}

In this study, using quantitative research methods and research design in the form of influence studies, namely to determine the effect of the three variables, namely the independent variable or free school infrastructure (X1), work environment (X2) and the dependent or dependent variable Teacher Performance (Y). The two independent variables, namely Infrastructure (X1) and Work Environment (X2), are associated with the dependent variable, namely teacher performance $(\mathrm{Y})$ with the pattern of the relationship between the infrastructure X1 variable and teacher $\mathrm{Y}$ performance, then the relationship between the work environment variable $\mathrm{X} 2$ and the teacher's performance $\mathrm{Y}$ and jointly relationship means infrastructure $\mathrm{X} 1$ and work environment X2 with teacher performance variable $\mathrm{Y}$. The data collection technique here is aimed at obtaining a score that functions as the direction of the relationship between the level of education, infrastructure and work environment on the performance of teachers at SD Negeri Gugus 3, Lengkiti District. The techniques used to collect data consist of: Questionnaire, Observation, Documentation.

\section{Results and Discussions}

\section{First Hypothesis}

Based on the results of data acquisition, the correlation coefficient value is obtained, namely 0.161 from this value, indicating that the infrastructure facilities variable is very weak against the teacher performance variable. Whereas for the coefficient of determination / R squer obtained 0.026 or $2.6 \%$ and the obtained sig value is $0.185>0.05$ means that H0 is accepted, which means that the value of $2.6 \%$ can affect teacher performance from the infrastructure and infrastructure variables and the rest is the influence of factors other.

Table $1<$ The Linear Constanta Regensia Equation>

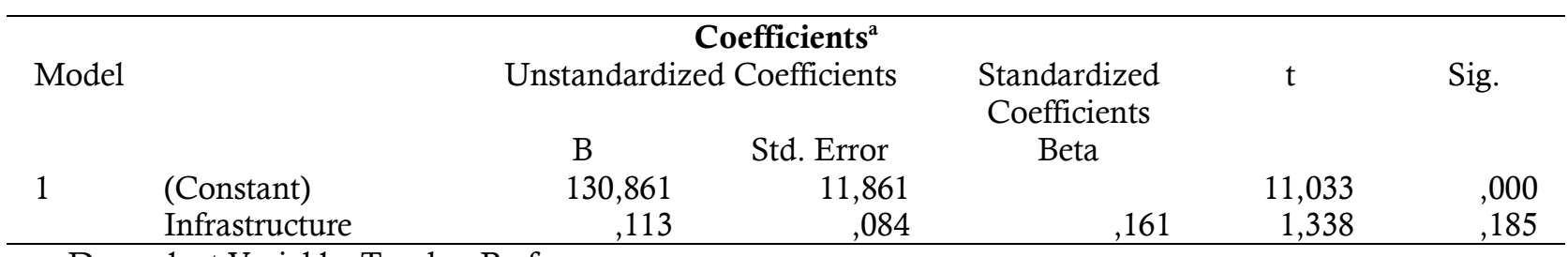

a. Dependent Variable: Teacher Performance

Based on the calculation, the linear constanta regensia equation is obtained is 130.861 and the coefficient value of the infrastructure and infrastructure variable is 0.113 . From this acquisition, the following equation can be made, namely $\mathrm{Y}=130.861+0.113 \mathrm{X}$. This means that the value of the variable $\mathrm{x}$ independent variable, namely the infrastructure variable with the acquisition value of 0.113 , which if the value is $0-1$ or close to 1 means that the variable shows that the higher the ability of the independent variable to explain the variance of 
the dependent variable Meanwhile, the t value in the lineier regensia table is 1.336 and the sig value. What you get is 0.185 . For the $t$ value $<1.666$, the $t$ value does not meet the requirements. However, the sig value obtained is $>0.05$, the sig value on the infrastructure and infrastructure variables states that there is no effect on teacher performance.

\section{Second Hypothesis}

Based on the results of data acquisition, the correlation coefficient value is 0.253 from this value, indicating that the work environment variable is weak against the teacher performance variable. Meanwhile, the coefficient of determination / $\mathrm{R}$ squer is 0.064 or $6.4 \%$, which means that the value of $6.4 \%$ can affect teacher performance from work environment variables and the rest is the influence of other factors.

Table $2<$ Teacher Performance from Work Environment Variables and the Rest is the Influence>

\begin{tabular}{|c|c|c|c|c|c|c|}
\hline \multicolumn{7}{|c|}{ Coefficients $^{\mathrm{a}}$} \\
\hline \multicolumn{2}{|c|}{ Model } & Unstandardiz & Coefficients & \multirow{2}{*}{$\begin{array}{l}\text { Standardized } \\
\text { Coefficients } \\
\text { Beta }\end{array}$} & \multirow[t]{2}{*}{$\mathrm{t}$} & \multirow[t]{2}{*}{ Sig. } \\
\hline \multirow{3}{*}{1} & & B & Std. Error & & & \\
\hline & (Constant) & 92,100 & 10,738 & & 8,577 &, 000 \\
\hline & $\begin{array}{l}\text { Work } \\
\text { environment }\end{array}$ & 204 &, 095 & 253 & 2,138 & ,036 \\
\hline
\end{tabular}

a. Dependent Variable: Teacher Performance

Based on the calculation, the linear constant regression equation is 92.100 and the coefficient value of the work environment variable is 0.204 . From this acquisition, the following equation can be made, namely $\mathrm{Y}=$ $92.100+0.204 X$.

This means that the value of the variable $\mathrm{x}$ independent variable is the work environment variable with a value of 0.204 , which means that if the value is $0-1$ or close to 1 , it means that the independent variable's ability to explain the variance of the dependent variable is higher. Meanwhile, the $t$ value in the linear regensia table is 2.138 and the sig value. The result is 0.036 . For the $t$ value $>1.666$, the $t$ value meets the requirements or there is an influence of work environment variables on teacher performance. Whereas the sig value obtained is $<0.05$, the sig value on the infrastructure and infrastructure variables states that there is an influence on teacher performance.

\section{Third Hypothesis}

Based on data acquisition, it shows that in making decisions on the multiple correlation test, which is seen from the Sig F Change value of $0.045<0.05$, the two variables of infrastructure and work environment can correlate or have a mutual influence on the teacher performance variable. And for the level of strength of the correlation between the two variables $\mathrm{X}$ to variable $\mathrm{Y}$ is moderate which can be seen in the correlation coefficient column (r) which is equal to 0.499 .

Table $3<$ The Correlation Coefficient Column (R)>

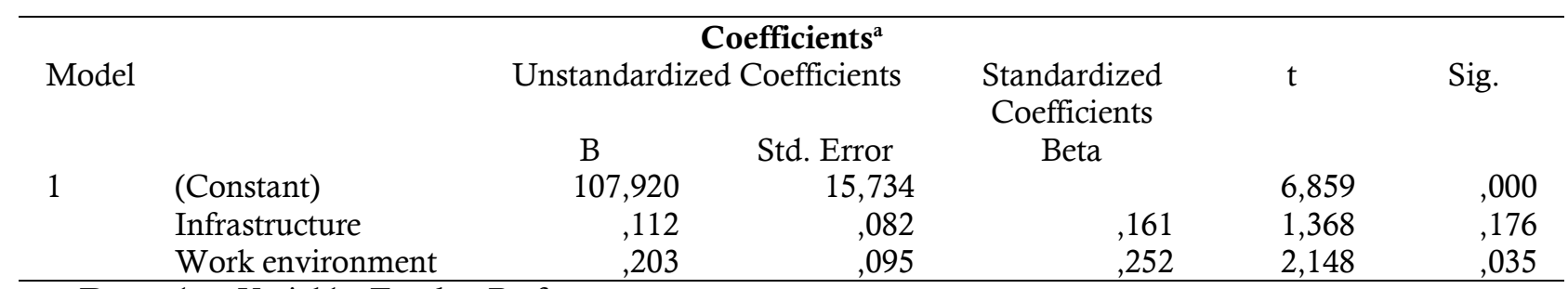

a. Dependent Variable: Teacher Performance

Based on the calculation, it is found that the constant value of the regression equation a is 107.920 and the coefficient value of the independent variable $b 1$ is 0.112 and $b 2$ is 0.203 , then the regression equation is obtained as follows. $\mathrm{Y}=107.920+0.112 \mathrm{X} 1+0.203 \mathrm{X} 2$. This means that teacher performance has increased positively with school infrastructure and work environment. In addition, to find out the truth of hypothesis testing, simultaneous testing is carried out. 


\section{Influence of Infrastructure Facilities on Teacher Performance}

The results showed that school infrastructure did not significantly influence the performance of teachers at $\mathrm{SD}$ Negeri Gugus $3 \mathrm{Kec}$. Lengkiti that is equal to $2.6 \%$. The results show that the better the school infrastructure, the better the teacher's performance. This study also shows that the strength of the infrastructure value is very weak, which is 0.161 in the correlation coefficient.

To support this research, a comparison can be seen in the discussion of previous studies which shows that many theories state the factors that support teacher performance in learning, one of which is school infrastructure. With adequate infrastructure, teachers will be helped to carry out varied, interesting and meaningful learning activities. This is in line with the results of research by Fauziana (2017) which states that there is a significant influence between school infrastructure and teacher performance by $25.4 \%$. In addition to the above research there are also several other studies that show the acquisition of the same research results which state that there is a positive and significant effect of school infrastructure on teacher performance.

Some of these studies were conducted by M. Yuri (2009), research by Almunfarijah (2014), as well as research conducted by Melly (2018) and the last one where the results of the research carried out had the same results obtained, the research was conducted by Hartono ( 2014) which states that in his research there is a partially significant influence of school infrastructure on teacher performance. Complete facilities and infrastructure will encourage and motivate teachers in carrying out teaching and learning activities so that teachers are better able to improve their abilities in making teaching and learning activities more attractive and maximized.

Teachers who are equipped with adequate infrastructure will show good performance than teachers who are not equipped with adequate facilities and infrastructure. And in this study, it is emphasized that the infrastructure is needed in improving teacher performance. Because in this study it shows that the value of infrastructure in the place under study still does not really highlight the usefulness and benefits of school presara in improving the performance of teachers in each school. The results of the value acquisition can be seen in the research results section above or can be seen in the attachment sheet for the study.

\section{The Effect of Work Environment on Teacher Performance}

Based on the results of hypothesis 2 testing, it is known that the work environment has a significant effect on teacher performance as shown by the results of the $t$ test, the $t$ value is $2.138>t$ table. At a significant level of 0.05 with a dterminan coefficient of 0.064 , it can be concluded that teacher performance is influenced by the work environment by $6.4 \%$. The results of the study show that the work environment variable has an influence on teacher performance, it's just that the coefficient of correlation is still weak, so it needs special attention from both researchers. However, for the whole work environment variables can be used to improve teacher performance. The weak value obtained was due to several factors that influenced the research. In addition, the lack of accuracy when processing data is also very influential, while the population itself has such a big role, where it can be seen that the population value used is a maximum of 100 populations, the value of the results obtained will also be greater.

Based on the results of research that has been compiled, it shows that the work environment has a positive influence on teacher performance. A good work environment will make teachers feel safe, comfortable, in carrying out teaching and learning activities so that teachers are better able to improve the quality of their learning. The work environment in schools describes the conditions of work both physical and non-physical which can affect teachers in carrying out their duties as teachers and educators.

This is supported by Hartono's previous research (2014) that there is a significant influence between the work environment and teacher performance based on partial regression analysis, it is obtained Fcount $>$ Ftable, $2.222>2.002$, so it is concluded that there is an influence of the work environment on teacher performance so that it can be accepted and tested. the truth. Apart from that, Bekti's (2005) research results in a study that shows that there is a positive and significant influence of the work environment on teacher performance. Furthermore, based on research conducted by Didi (2014) which results in a dominant influence of the work environment on teacher performance. Another supporting research that obtained the same results is research conducted by Dyah (2017) which states that his research shows that there is a significant effect of the environment on teacher performance. Seeing from the research conducted by Almunafarijah (2014) which states that the results of the research he conducted are the same as this research, where the results show that there is a positive and significant effect of the work environment on teacher performance. And the latest research conducted by Badawi (2014) shows that there is an influence and good criteria from the work environment on teacher performance. 


\section{The Effect of Infrastructure and Work Environment on Teacher Performance}

From the results of the study found that school infrastructure and work environment together have a significant effect on the performance of teachers at SD Negeri Gugus 3 Kec. Lengkiti by 59\%. From these findings it can be interpreted that school infrastructure facilities and the work environment together have a significant strength on teacher performance. Complete facilities and infrastructure will encourage and motivate teachers in carrying out teaching and learning activities so that teachers are better able to improve their abilities in processing learning activities. Likewise, if the creation of a positive work environment can improve the teacher's performance.

The significant value above the basis for taking multiple regression tests can also be seen from the value of Fcount $>$ Ftable $(3,250>3,13)$, it can be concluded that $\mathrm{Ha}$ is accepted, so Ho is rejected, then the infrastructure and work environment have an influence on the performance of SD Negeri teachers. Gugus 3 Kec. Sticky.

The results of this study are in line with research conducted by Handayani (2004). Based on the results of multiple regression analysis, it was obtained $\mathrm{F} \neg$ hiting $>$ Ftable $=13.727>2.760$. Therefore, it can be concluded that the effect of the level of education, infrastructure and work environment on teacher performance is accepted and verified. In addition to research that is in line with ditas, there are also several similar studies including research conducted by Damayanti (2018) which shows that school infrastructure and work environment together have a significant effect on teacher performance.

Research conducted by Hartono (2014) states that in his research that the infrastructure and work environment together have an influence on teacher performance. And research conducted by Fauziana (2017) states the same results, namely that there is a positive and significant influence or partially and simultaneously simultaneously from the goals of the school and work environment on teacher performance.

\section{Conclusions}

Based on the results of the research and discussion, it can be concluded as follows: 1) There is a significant influence between school infrastructure and the performance of teachers at SD Negeri Gugus 3, Lengkiti District, 2) There is a significant influence between the work environment on the performance of teachers at SD Negeri Gugus 3, Lengkiti District, 3 ) There is a significant influence between school infrastructure and the environment together on the performance of teachers at SD Negeri Gugus 3, Lengkiti District.

\section{References}

Angrainy, A., Fitria, H., \& Fitiani, Y.(2020). Pengaruh Sarana Prasarana dan Lingkungan Kerja terhadap Kinerja Guru. Journal of Education Research, 1(2), 154-159

Barnawi dan Mohammad Arifin.(2013).Manajemen Sarana dan Prasarana Sekolah. Yogyakarta:Ar-Ruzz Media. Fauziana, Dyah.(2017). Pengaruh Sarana Prasarana dan Lingkungan Kerja Terhadap Kinerja Guru di Pondok Pesantren Al-Islam Joresan MLarak Ponorogo.Jawa Timur; IAIN Ponorogo.

Hartono, Didi.(2014). Pengaruh sarana Prasarana dan Lingkungan Kerja terhadap Kinerja Pegawai Dinas Pendidikan Kota banjar Baru. Junal Kindai Vol.10 No.2 .

Mulyasa. (2013). Uji Kompetensi dan Penilaian Kinerja Guru. Bandung: PT Remaja Rosdakarya

Supardi. (2013). Kinerja Guru. Jakarta : Rajawali Pers.

Syafarudin. (2008). Efektifitas Kebijakan Pendidikan. Jakarta: Rineka Cipta.

Undang-undang Nomor 20 Tahun 2013 Tentang Sistem Pendidikan Nasional.

Usman, Husaini. (2008). Manajemen Teori Praktik dan Riset Pendidikan. Jakarta: Bumi Aksara.

Yusutria. (2017). "Profesionalisme Guru dalam Meningkatkan Kualitas Sumber daya Manusia." Jurnal Curricula Vol.2 No.1. 